\title{
Prolonged QRS independently predicts long-term all-cause mortality in patients with narrow QRS complex undergoing coronary artery bypass grafting surgery (9-year follow-up results)
}

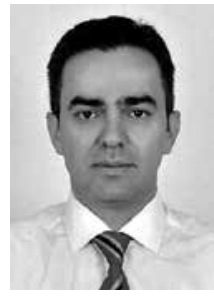

Turan Erdoğan ${ }^{1}$, Mustafa Çetin ${ }^{1}$, Ali Gökhan Özyıldız², Savaş Özer ${ }^{2}$, Abdülkadir Uslu ${ }^{3}$, Sedat Ozan Karakişi ${ }^{4}$, Tuncay Kırış

${ }^{1}$ Department of Cardiology, Faculty of Medicine, Recep Tayyip Erdoğan University, Rize, Turkey

${ }^{2}$ Department of Cardiology, Recep Tayyip Erdoğan University, Training and Research Hospital, Rize, Turkey

${ }^{3}$ Department of Cardiology, Kartal Koşuyolu Training and Research Hospital, İstanbul, Turkey

${ }^{4}$ Department of Cardiovascular Surgery, Faculty of Medicine, Recep Tayyip Erdoğan University, Rize, Turkey

${ }^{5}$ Department of Cardiology, Katip Çelebi University, Atatürk Training and Research Hospital, Izmir, Turkey

Kardiochir Torakochir Pol 2020; 17 (3): 117-122

\begin{abstract}
Aim: We investigated the association of intermediate QRS prolongation with the long-term all-cause mortality in coronary artery bypass grafting (CABG) surgery patients with a narrow QRS complex in the preoperative electrocardiography (ECG).

Material and methods: A total of 221 consecutive patients with narrow QRS (< $120 \mathrm{~ms}$ ) sinus rhythm who underwent CABG surgery were included in the study. The patients were followed up for 9.2 years postoperatively in terms of mortality outcomes.

Results: Follow-up data were obtained from 211 (173 men, 38 women) of 221 patients. Death occurred in 57 of them. We examined patients in the two groups according to survival outcomes. In multivariate COX regression analysis EuroSCORE $(\mathrm{OR}=1.342,95 \% \mathrm{Cl}: 1.167-1.544, p<0.001)$, extent of coronary artery disease $(\mathrm{OR}=1.768,95 \% \mathrm{Cl}: 1.034-3.020, p=0.037)$, QRS duration $(\mathrm{OR}=1.029,95 \% \mathrm{Cl}: 1.002-1.058, p=0.035)$ and fasting glucose levels (OR $=0.992,95 \% \mathrm{Cl}$ : 0.984-0.999, $p=0.029$ ) were independent predictors of all-cause mortality. QRS duration > 89.5 ms determined all-cause mortality with a sensitivity of $73.7 \%$ and a specificity of $52 \%(O R=2.07)$ due to ROC analysis. All-cause mortality was significantly higher in patients with preop QRS duration $>90 \mathrm{~ms}$ from the first year $\left(\chi^{2}=6.724, p=0.010\right)$.
\end{abstract}

Conclusions: In CABG patients with a narrow QRS complex, preoperative intermediate prolonged QRS is an independent predictor of all-cause mortality in long-term follow-up.

Keywords: coronary artery bypass grafting, QRS duration, allcause mortality, long-term follow-up.

\section{Streszczenie}

Cel pracy: W pracy analizowano zależność między umiarkowanym wydłużeniem czasu trwania QRS a długoterminową śmiertelnością z jakiejkolwiek przyczyny u pacjentów z wąskim zespotem QRS w przedoperacyjnym badaniu elektrokardiograficznym (EKG) poddanych pomostowaniu tętnic wieńcowych (CABG).

Materiat i metody: Do badania włączono 221 kolejnych pacjentów z rytmem zatokowym i wąskim zespołem QRS (< $120 \mathrm{~ms}$ ), u których wykonano zabieg CABG. Pacjentów poddano obserwacji pod kątem śmiertelności przez okres 9,2 roku od operacji. Wyniki: Dane z obserwacji uzyskano dla 211 (173 mężczyzn, 38 kobiet) spośród 221 pacjentów. Zgon nastąpił u 57 osób. Pacjentów analizowano $w$ dwóch grupach w zależności od wyników przeżycia. W wieloczynnikowej analizie regresji Coxa wynik w skali EuroSCORE (OR $=1,342 ; 95 \% \mathrm{Cl}: 1,167-$ 1,544, $p<0,001)$, zasięg choroby wieńcowej (OR $=1,768 ; 95 \%$ Cl: $1,034-3,020 ; p=0,037)$, czas trwania QRS (OR = 1,029; 95\% Cl: 1,002-1,058, $p=0,035)$ oraz stężenie glukozy na czczo (OR = 0,992; 95\% Cl: 0,984-0,999; $p=0,029)$ stanowity niezależne predyktory długoterminowej śmiertelności z jakiejkolwiek przyczyny. Na podstawie analizy ROC czas trwania QRS > 89,5 ms pozwalał przewidzieć śmiertelność z czułością rzędu 73,7\% i swoistością rzędu 52\% (OR = 2,07). Śmiertelność z jakiejkolwiek przyczyny była znamiennie wyższa u pacjentów z przedoperacyjnym czasem trwania QRS > 90 ms już od pierwszego roku $\left(\chi^{2}=6,724 ; p=0,010\right)$.

Wnioski: W długoterminowej obserwacji przedoperacyjne umiarkowane wydłużenie czasu trwania QRS u chorych z wąskim zespołem QRS poddanych CABG stanowi niezależny predyktor śmiertelności z jakiejkolwiek przyczyny.

Słowa kluczowe: pomostowanie tętnic wieńcowych, czas trwania zespołu QRS, śmiertelność z jakiejkolwiek przyczyny, obserwacja długoterminowa.

Address for correspondence: Ali Gökhan Özyıldız MD, Department of Cardiology, Recep Tayyip Erdoğan University, Training and Research Hospital, Rize, Turkey, e-mail: aligokhanozyildiz@gmail.com Received: 23.06.2020, accepted: 28.08.2020. 


\section{Introduction}

Surface 12-lead electrocardiography (ECG) is commonly used in cardiology practice. Besides being a guide in diagnosis and treatment, it is low in cost, noninvasive, and easy to apply. QRS duration (QRSd) is an ECG parameter and shows left and right ventricular depolarization time [1]. The QRSd differs in healthy individuals, and $>120 \mathrm{~ms}$ is referred to as wide QRS (wQRS), while $\leq 120 \mathrm{~ms}$ is considered as narrow QRS (nQRS) [2]. Many factors affect the duration of QRS, such as left ventricular hypertrophy or dilatation, His-Purkinje conduction defect, left or right bundle branch block, intramyocardial conduction defect, and antiarrhythmic drug use. One of the crucial factors associated with QRS prolongation ( $\uparrow \mathrm{QRS}$ ) is left ventricular systolic dysfunction [2, 3].

QRS prolongation causes poor cardiovascular outcomes [2, 4-7]. In the left bundle branch block (LBBB), a mortality increase is prominent, but cardiac resynchronization therapy is effective by shortening the QRSd $[8,9]$. QRS prolongation is a poor prognostic marker in patients undergoing coronary artery bypass surgery (CABG), as in other cardiovascular diseases [10-12].

In community-based studies, it has been shown that a QRS duration > 110 ms is associated with increased sudden cardiac death, and in those with a fractional shortening below the average value, each increase of $10 \mathrm{~ms}$ is an independent predictor of sudden cardiac death [13]. Even in patients with narrow QRS, intermediate QRS prolongation (QRS 90-110 ms) is associated with poor cardiovascular outcomes $[14,15]$.

\section{Aim}

In the current study, we examined the relationship between QRS duration and long-term survival in patients with narrow QRS, who underwent isolated CABG.

\section{Material and methods}

The study is a retrospective cohort study. A total of 211 consecutive patients who were admitted to our cardiology clinic between January 2008 and August 2010 and underwent an isolated CABG operation were included in the research. We followed the patients for an average of 110.6 \pm 16.8 months and identified all-cause mortality as an endpoint. Patients' death information was obtained from the official national population registration system, and the clinical data were provided through a medical record system. We performed the study under the principles stated in the Declaration of Helsinki. The local ethics committee approved the protocol.

We recorded the patients' baseline characteristics, laboratory, echocardiographic and ultrasonographic parameters from the routine preoperative assessments. The EuroSCORE calculation was performed using the original score calculation tool available at http://www.euroscore.org/calc.html. We defined preoperative myocardial infarction and chronic obstructive pulmonary disease according to guidelines [16,
17]. Carotid stenosis was evaluated with preoperative carotid Doppler ultrasonography. Body mass index (BMI) was calculated by the weight/height ${ }^{2}$ formula. The treatment of the patients was arranged according to the coronary artery disease guidelines before the CABG operation.

Preoperative QRSd > 120 ms was defined as wide QRS, and patients with wide QRS were excluded; preoperative QRSd $<120$ ms was defined as narrow QRS, and patients with narrow QRS were included in the study. We planned to examine the effect of QRSd on mortality.

Patients with acute or chronic renal failure, history of CABG, or any other cardiovascular surgery, chronic liver disease, malignancy, QRSd > $120 \mathrm{~ms}$, and other than sinus rhythm were excluded from the study. Hospital deaths and patients with unavailable data were not included in the analysis.

Standard transthoracic and Doppler echocardiographic examinations were performed using a 3.25- $\mathrm{MHz}$ transthoracic transducer connected to a Vivid 5 System (GE Vingmed Ultrasound AS, Horten, Norway). Two cardiologists, blinded to patients' data, performed the echocardiography. Left ventricular ejection fraction (LVEF) was calculated with the Simpson method, and other echocardiographic parameters were evaluated according to the American Society of Echocardiography guidelines [18].

Electrocardiography recordings were taken at $50 \mathrm{~mm} / \mathrm{s}$ and $10 \mathrm{mV} / \mathrm{mm}$ amplitude by placing the leads in the standard position. Two expert cardiologists, blinded to patients' data, evaluated the ECG records, and calculated the most extended QRSd in the leads [19-21].

\section{Statistical analysis}

Continuous variables were presented as mean values (standard deviation (SD)) or medians with ranges, and the categorical variables were expressed as percentages. The variables were compared using a 2-tailed Student's $t$-test for the continuous variables of a normal distribution or the Mann-Whitney $U$ test for non-normal distribution. The $\chi^{2}$ test was used for the categorical variables. The effects of the various variables on all-cause mortality were calculated by univariate Cox regression analysis. In these analyses, the variables with unadjusted $p<0.1$ were identified as confounding factors and included in the multivariate regression analyses to determine the independent predictors of all-cause mortality. Factors included in EuroSCORE (age, carotid stenosis, LVEF) were not included in the multivariate analysis. Factors with $p<0.05$ in the univariate analysis (EuroSCORE, QRSd, number of coronary arteries with $>50 \%$ stenosis, fasting glucose level) were included in the multivariate Cox regression analysis, and the stepwise forward method was used. All the analyses were carried out using SPSS version 16 (SPSS, Inc., Chicago, Illinois).

\section{Results}

A total of 211 patients (173 men, 38 women) were followed up to $9.2 \pm 1.6$ years, and 57 (27\%) patients died after discharge from the hospital (Table I). When the survivors and 
Table I. Comparison of demographic data

\begin{tabular}{|c|c|c|c|}
\hline Variable & Survivors $(n=154)$ & Non-survivors $(n=57)$ & $P$-value \\
\hline Age, mean \pm SD [years] & $59.4 \pm 8.9$ & $66.4 \pm 9.2$ & $<0.001$ \\
\hline Gander (female), $n$ (\%) & $27(17.5)$ & $10(17.5)$ & 0.572 \\
\hline Body-mass index $\left[\mathrm{kg} / \mathrm{m}^{2}\right]$ & $28.6 \pm 4.3$ & $28.3 \pm 4.3$ & 0.777 \\
\hline Diabetes mellitus, $n(\%)$ & 75 (48.7) & 19 (33.3) & 0.032 \\
\hline Dyslipidemia, $n(\%)$ & $85(55.6)$ & $31(54.4)$ & 0.501 \\
\hline Hypertension, $n(\%)$ & $87(57.5)$ & $42(73.7)$ & 0.069 \\
\hline Current smoking, $n(\%)$ & $71(46.7)$ & $29(50.9)$ & 0.322 \\
\hline EuroSCORE & $2.76 \pm 1.6$ & $4.5 \pm 2.1$ & $<0.001$ \\
\hline COPD, $n(\%)$ & $24(15.7)$ & $14(24.6)$ & 0.101 \\
\hline Previous MI, $n$ (\%) & $65(42.2)$ & $27(48.2)$ & 0.268 \\
\hline QRS duration, mean \pm SD & $89.1 \pm 9.7$ & $94.7 \pm 9.9$ & $<0.001$ \\
\hline Severe carotid stenosis, $n(\%)$ & $5(3.3)$ & $8(14.3)$ & 0.007 \\
\hline LMCA involvement, $n(\%)$ & 17 (12.6) & $4(8.2)$ & 0.292 \\
\hline LVEF\% & $53.7 \pm 13.1$ & $46.6 \pm 12.9$ & $<0.001$ \\
\hline Number of $C A D$ & $2.45 \pm 0.68$ & $2.63 \pm 0.69$ & 0.017 \\
\hline Number of saphenous vein grafts & $2.97 \pm 1$ & $2.92 \pm 0.96$ & 0.579 \\
\hline LIMA usage, $n(\%)$ & $145(95.4)$ & $51(89.5)$ & 0.107 \\
\hline Cross-clamp time [min] & $58.3 \pm 23.2$ & $64.1 \pm 22.5$ & 0.047 \\
\hline Off-pump surgery, $n$ (\%) & $16(10.8)$ & $7(12.3)$ & 0.374 \\
\hline Fasting glucose [mg/dl] & $138.6 \pm 63.5$ & $115.9 \pm 37.5$ & 0.016 \\
\hline Serum creatine [mg/dl] & $0.98 \pm 0.26$ & $1.04 \pm 0.18$ & 0.347 \\
\hline WBC $\left[\times 10^{3} / \mathrm{mm}^{3}\right]$ & $8.04 \pm 2.03$ & $7.6 \pm 2.07$ & 0.782 \\
\hline Neutrophils $\left[\times 10^{3} / \mathrm{mm}^{3}\right]$ & $5.01 \pm 1.9$ & $4.6 \pm 1.51$ & 0.890 \\
\hline Hemoglobin [g/dl] & $13.5 \pm 1.27$ & $13.1 \pm 1.5$ & 0.048 \\
\hline Acetylsalicylic acid, $n(\%)$ & $152(98.7)$ & $54(94.7)$ & 0.896 \\
\hline Clopidogrel, $n(\%)$ & $39(25.3)$ & $19(33.3)$ & 0.163 \\
\hline ACE/ARB, $n(\%)$ & $78(50.6)$ & $34(59.6)$ & 0.247 \\
\hline $\mathrm{CCB}, n(\%)$ & $26(16.9)$ & $9(15.8)$ & 0.516 \\
\hline$\beta$-Blocker, $n(\%)$ & $111(72.1)$ & $38(66.7)$ & 0.273 \\
\hline Insulin/OAD, $n$ (\%) & $70(45.5)$ & $16(28.1)$ & 0.016 \\
\hline Statin, $n(\%)$ & $147(95.4)$ & $53(92.9)$ & 0.878 \\
\hline
\end{tabular}

ACE - angiotensin converting enzyme inhibitor, ARB - angiotensin renin inhibitor, CAD - coronary artery disease, CCB - calcium channel blocker, COPD - chronic obstructive pulmonary disease, HDL - high-density lipoprotein, LIMA - left internal mammary artery, LMCA - left main coronary artery, LVEF - left ventricular ejection fraction, MI - myocardial infarction, NSTEMI - non-ST elevation myocardial infarction, OAD - oral anti-diabetic, WBC - white blood cells.

non-survivors were compared the mean age (66.4 \pm 9.2 vs. $59.4 \pm 8.9$ years; $p<0.001)$, EuroSCORE $(4.5 \pm 2.1$ vs. $2.76 \pm 1.6$; $p<0.001)$, severe carotid stenosis (8 (14.3\%) vs. 5 (3.3\%); $p=0.007)$, and number of coronary arteries with stenosis (2.63 \pm 0.69 vs. $2.45 \pm 0.68$; $p=0.017$ ), were lower; furthermore, QRSd (94.7 $\pm 9.9,89.1 \pm 9.7 \mathrm{~ms} ; p<0.001)$ and duration of bypass ( $64.1 \pm 22.5$ vs. $58.3 \pm 23.2 \mathrm{~min} ; p=0.047)$ were shorter in the survivor group. Left ventricular ejection fraction $(46.6 \pm 12.9 \%, 53.7 \pm 13.1 \% ; p<0.001)$ and hemoglobin levels $(13.1 \pm 1.5,13.5 \pm 1.27 \mathrm{~g} / \mathrm{dl} ; p=0.048)$ were higher in the survival group. Paradoxically, diabetes (19 (33.3\%) vs. $75(48.7 \%) ; p=0.032)$, insulin/oral antidiabetic usage (16 (28.1\%) vs. $70(45.5 \%) ; p=0.016)$, and fasting glucose levels (115.9 \pm 37.5 vs. $138.6 \pm 63.5 \mathrm{mg} / \mathrm{dl}$; $p=0.016)$ were higher in the survival group.

In univariate Cox regression analysis age $(O R=1.076$, 95\% Cl: 1.042-1.110, $p<0.001)$, EuroSCORE (OR $=1.364$,
95\% Cl: $1.226-1.517, p<0.001)$, LVEF (OR $=0.957,95 \% \mathrm{Cl}$ : $0.937-9.978, p<0.001)$, severe carotid stenosis $(O R=1.805$, $95 \% \mathrm{Cl}: 1.237-2.632, p=0.002)$, extent of CAD (OR $=1.694$, $95 \% \mathrm{Cl}: 1.033-2.776, p=0.037)$, QRSd (OR $=1.049 ; 95 \%$ $\mathrm{Cl}: 1.023-1.075, p<0.001)$, and fasting glucose levels (OR $=0.994,95 \% \mathrm{Cl}: 0.998-1.000, p=0.039)$ were associated with all-cause mortality (Table II). In multivariate Cox regression analysis using the forward stepwise method EurOSCORE (OR $=1.342,95 \% \mathrm{Cl}: 1.167-1.544, p<0.001)$, extent of CAD (OR $=1.768,95 \% \mathrm{Cl}: 1.034-3.020, p=0.037)$, QRSd (OR $=1.029,95 \% \mathrm{Cl}: 1.002-1.058, p=0.035)$ and fasting glucose levels $(\mathrm{OR}=0.992,95 \% \mathrm{Cl}$ : 0.984-0.999, $p=0.029)$ were independent predictors of all-cause mortality. QRS duration $>89.5$ ms determined all-cause mortality with a sensitivity of $73.7 \%$ and a specificity of $52 \%(O R=2.07)$ due to ROC analysis. Comparing long-term survival of patients, all-cause mortality was significantly higher in pa- 
Prolonged QRS independently predicts long-term all-cause mortality in patients with narrow QRS complex undergoing coronary artery bypass grafting surgery (9-year follow-up results)

Table II. Factors predicting mortality (Cox regression analysis)

\begin{tabular}{|c|c|c|c|c|c|c|}
\hline \multirow[t]{2}{*}{ Parameter } & \multicolumn{3}{|c|}{ Univariate } & \multicolumn{3}{|c|}{ Multivariate } \\
\hline & OR & $95 \% \mathrm{Cl}$ & $P$-value & OR & $95 \% \mathrm{Cl}$ & $P$-value \\
\hline Age $^{*}$ [years] & 1.076 & $1.042-1.110$ & $<0.001$ & & & \\
\hline Diabetes & 0.660 & $0.379-1.149$ & 0.142 & & & \\
\hline EuroSCORE & 1.364 & $1.226-1.517$ & $<0.001$ & 1.342 & $1.167-1.544$ & $<0.001$ \\
\hline QRS duration & 1.049 & $1.023-1.075$ & $<0.001$ & 1.029 & $1.002-1.058$ & 0.035 \\
\hline Severe carotid stenosis* & 1.805 & $1.237-2.632$ & 0.002 & & & \\
\hline LVEF\%* $^{*}$ & 0.957 & $0.937-9.978$ & $<0.001$ & & & \\
\hline Number of CAD & 1.694 & $1.033-2.776$ & 0.037 & 1.768 & $1.034-3.020$ & 0.037 \\
\hline Cross-clamp time [min] & 1.011 & $0.997-1.024$ & 0.120 & & & \\
\hline Fasting glucose [mg/dl] & 0.994 & $0.998-1.000$ & 0.039 & 0.992 & $0.984-0.999$ & 0.029 \\
\hline Hemoglobin $[\mathrm{g} / \mathrm{dl}]$ & 0.834 & $0.675-1.030$ & 0.092 & & & \\
\hline İnsulin/OAD & 0.581 & $0.325-1.039$ & 0.067 & & & \\
\hline
\end{tabular}

CAD - coronary artery disease, LVEF - left ventricular ejection fraction, OAD - oral anti-diabetic. *Not included in the multivariate analysis because it was Scored in EUROSCORE.

tients with preop QRS duration $>90 \mathrm{~ms}$, from the first year $\left(\chi^{2}=6.724, p=0.010\right)$ (Figure 1).

\section{Discussion}

We found that in patients scheduled to have an isolated CABG operation, prolonged QRS, even if it was $\leq 120 \mathrm{~ms}$, was an independent predictor of all-cause mortality over 9 years of follow-up. As QRS was prolonged, survival was significantly reduced at 9.2 years of follow-up.

In the long-term survival study conducted by Ramirez et al., 340 CABG patients were followed for 5 years, and the mortality group had a longer QRSd (100 ms vs. 92 ms; $p=0.021$ [ [10]. Nevertheless, QRSd was not an independent predictor of mortality in multivariate analysis. The mentioned study, which had a shorter follow-up time and different design than our study, determined that QRSd was not an independent predictor of mortality, yet it produced data that support our study.

Gomes et al. determined that QRSd > 114 ms as an independent predictor of cardiac arrest or arrhythmic death in patients with ischemic cardiomyopathy [22]. This finding supported the results of the GUST study [23]. Pudil

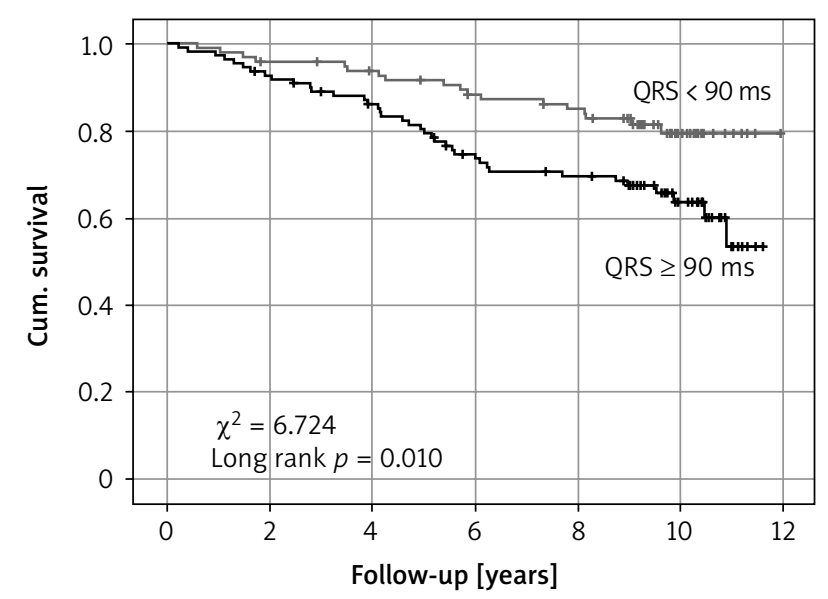

Figure 1. Kaplan-Meier survival curve et al. investigated the prognostic significance of QRSd in 1100 acute myocardial infarction patients [14]. The patients were divided into three groups as $<90 \mathrm{~ms}, 90-110 \mathrm{~ms}$, $>110 \mathrm{~ms}$, according to the QRS duration on the admission ECG. When the mortality data of 7 days, 30 days, and 1 year were compared, the mortality was significantly higher in the 90-110 ms group than the $<90$ ms group $(p<0.001)$. In addition, in the group with intermediate QRS prolongation, the peak CK-MB level was higher than in the group with QRS duration $<90 \mathrm{~ms}$, and intermediate QRS prolongation was an independent predictor of all-cause mortality in multivariate analysis $(O R=2.21)$. This research is essential to reveal the clinical significance of QRSd, even if it is a narrow QRS complex. Remarkably, in our study, the preop QRS duration of $>90 \mathrm{~ms}$ was the most sensitive and specific marker in determining the long-term prognosis, and there was a significant difference in the long term between the two groups in the Kaplan-Maier survival graph (Figure 1).

Some researchers have revealed that it is clinically significant to have $\geq 100 \mathrm{~ms}$ of QRSd without branch block, and defined it as intermediate QRS prolongation. Brilakis et al. reported that intermediate QRS prolongation is an independent predictor of in-hospital mortality in non-ST elevated myocardial infarction (MI) [24]. In a similar study, Tsukahara et al. revealed that ST elevated MI patients undergoing reperfusion had more severe CAD in those with intermediate QRS prolongation [25]. Ilkhanoff et al. evaluated the relationship between cardiac MR imaging, QRSd, and left ventricular (LV) structure in 4591 patients and found that LV volume and mass were higher, and LVEF was lower in patients with QRSd $>100$ ms [26]. Additionally, the incidence of heart failure was higher in patients with prolonged QRS in the 7.1 years of follow-up. Similarly, Kurisu et al. reported that intermediate QRS prolongation was positively associated with LV end-diastolic volume and LV endsystolic volume, and was inversely associated with LVEF, in patients with prior anterior MI [27]. Bader et al. stated that QRS prolongation is the most critical predictor of ventricu- 
lar electromechanical asynchrony, worsening prognosis in heart failure [28]. As a result, for patients with intermediate QRS prolongation, poor LV remodeling is prominent as in WQRS. Thus, intermediate QRS prolongation, clinically and prognostically, seems to mimic the wQRS complex.

Electrocardiography is a cost-effective and practical method that can help to predict sudden cardiac death (SCD) [29]. Increased QRSd is a higher risk for SCD [30]. Implantable cardioverter-defibrillator observational studies and subgroup analyses showed the benefit of narrowing QRS with electrical synchronization [31]. Teodorescu et al. evaluated the effect of prolonged ventricular depolarization and repolarization on the ventricular arrhythmia in CAD patients [32]. They found that 642 SCD cases detected from the general population had an increased QRSd of $8 \mathrm{~ms}$ compared to 473 control CAD patients.

The QRSd has a poor prognosis also in preserved LV systolic function. Hummel et al. demonstrated that QRSd is an essential indicator of long-term mortality in patients with preserved left ventricular systolic function hospitalized for heart failure [33]. Joseph et al. reported a similar result [34]. The patients of these studies had the wQRS complex. There are not enough data in the literature related to intermediate QRS prolongation.

In conclusion, for patients undergoing an isolated CABG operation, intermediate prolonged QRS affects prognosis in the long term. The causes are similar to the studies with the $W Q R S$ complex. So, in patients undergoing isolated CABG surgery, intermediate prolonged QRS may be a guide in determining long-term increased all-cause mortality risk.

Since the study was retrospective, cardiac death could not be distinguished; therefore, all-cause mortality data could be obtained. The effect of medical treatment on longterm mortality was not evaluated. The number of patients is limited. Only the QRS duration was taken into account in the ECGs of the patients. Fragmented QRS and QRS morphology were not evaluated in the study. Long-term prospective studies may better demonstrate the effectiveness of QRSd measurement, a simple and inexpensive method, in demonstrating long-term risk increases in for patients undergoing $C A B G$ surgery.

\section{Conclusions}

In patients with narrow QRS sinus rhythm undergoing isolated CABG surgery, intermediate prolonged QRS is an independent predictor of all-cause mortality in a 9.2-year follow-up.

\section{Disclosure}

The authors report no conflict of interest.

\section{References}

1. Abboud S, Berenfeld O, Sadeh D. Simulation of high-resolution QRS complex using a ventricular model with a fractal conduction system. Effects of ischemia on high-frequency QRS potentials. Circ Res 1991; 68: 1751-1760.

2. Fosbol EL, Seibaek M, Brendorp B, et al.; Arrhythmia ONDsg. Differential prognostic importance of QRS duration in heart failure and acute myocardial infarction associated with left ventricular dysfunction. Eur J Heart Fail 2007. 9: 814-819.

3. Murkofsky RL, Dangas G, Diamond JA, et al. A prolonged QRS duration on surface electrocardiogram is a specific indicator of left ventricular dysfunction. J Am Coll Cardiol 1998; 32: 476-482.

4. Freedman RA, Alderman EL, Sheffield LT, et al. Bundle branch block in patients with chronic coronary artery disease: angiographic correlates and prognostic significance. J Am Coll Cardiol 1987; 10: 73-80.

5. Iuliano S, Fisher SG, Karasik PE, et al.; Department of Veterans Affairs Survival Trial of Antiarrhythmic Therapy in Congestive Heart F. QRS duration and mortality in patients with congestive heart failure. Am Heart J 2002; 143: 1085-1091.

6. Triola B, Olson MB, Reis SE, et al. Electrocardiographic predictors of cardiovascular outcome in women: the National Heart, Lung, and Blood Institutesponsored Women's Ischemia Syndrome Evaluation (WISE) study. J Am Coll Cardiol 2005; 46: 51-56.

7. Elhendy A, Hammill SC, Mahoney DW, Pellikka PA. Relation of QRS duration on the surface 12-lead electrocardiogram with mortality in patients with known or suspected coronary artery disease. Am J Cardiol 2005; 96: 10821088.

8. Scherbak D, Hicks GJ. Left Bundle Branch Block (LBBB). StatPearls Treasure Island (FL) 2019.

9. Hadjis A, AlTurki A, Proietti R, et al. Predicting response to cardiac resynchronization therapy: use of strict left bundle branch block criteria. Pacing Clin Electrophysiol 2019; 42: 431-438.

10. Ramírez ML, Abi-rezk MN, Liriano HM, et al. ORS duration and its relationship with the postoperative mortality of the coronary artery bypass grafting surgery. Cuban Soc Cardiol 2018; 1: 4-12.

11. Ozcan S. Relationship between atrial fibrillation and coronary bypass surgery. Pak J Med Sci 2014; 30: 630-633.

12. Acil T, Turkoz R, Acil M, et al. Value of prolonged QRS duration as a predictor of low cardiac output syndrome in patients with impaired left ventricular systolic function who undergo isolated coronary artery bypass grafting. Am J Cardiol 2006; 98: 1357-1362

13. Kurl S, Makikallio TH, Rautaharju P, et al. Duration of QRS complex in resting electrocardiogram is a predictor of sudden cardiac death in men. Circulation 2012; 125: 2588-2594.

14. Pudil R, Feinberg MS, Hod H, et al. The prognostic significance of intermediate QRS prolongation in acute myocardial infarction. Int J Cardiol 2001; 78: 233-239.

15. Taskesen T, Kaya I, Alyan O, et al. Prognostic value of the Intermediate QRS prolongation in patients with acute myocardial infarction. Clin Ter 2014; 165: e153-e157.

16. Thygesen K, Alpert JS, White HD, et al. Universal definition of myocardial infarction. Circulation 2007; 116: 2634-2653.

17. Minas M, Dimitropoulos K, Pastaka C, et al. Global initiative for chronic obstructive lung disease for chronic obstructive pulmonary disease: GOLD opportunity for lung disorders. Prev Med 2005; 40: 274-277.

18. Cheitlin MD, Armstrong WF, Aurigemma GP, et al., American College of $C$, American Heart A and American Society of E. ACC/AHA/ASE 2003 guideline update for the clinical application of echocardiography: summary article: a report of the American College of Cardiology/American Heart Association Task Force on Practice Guidelines (ACC/AHA/ASE Committee to Update the 1997 Guidelines for the Clinical Application of Echocardiography). Circulation 2003; 108: 1146-1162.

19. Wagner GS, Macfarlane P, Wellens H, et al., American Heart Association E, Arrhythmias Committee CoCC, American College of Cardiology F and Heart Rhythm S. AHA/ACCF/HRS recommendations for the standardization and interpretation of the electrocardiogram: part VI: acute ischemia/infarction: a scientific statement from the American Heart Association Electrocardiography and Arrhythmias Committee, Council on Clinical Cardiology; the American College of Cardiology Foundation; and the Heart Rhythm Society. Endorsed by the International Society for Computerized Electrocardiology. J Am Coll Cardiol 2009; 53: 1003-1011.

20. Prineas RJ, Crow RS, Zhang Z. The Minnesota Code Manual of Electrocardiographic Findings. Boston, Springer 2010.

21. Crow RS, Prineas RJ, Hannan PJ, et al. Prognostic associations of Minnesota Code serial electrocardiographic change classification with coronary heart disease mortality in the Multiple Risk Factor Intervention Trial. Am J Cardiol 1997; 80: 138-144

22. Gomes JA, Cain ME, Buxton AE, et al. Prediction of long-term outcomes by signal-averaged electrocardiography in patients with unsustained ventricu- 
lar tachycardia, coronary artery disease, and left ventricular dysfunction. Circulation 2001; 104: 436-441.

23. GUSTO investigators. An international randomized trial comparing four thrombolytic strategies for acute myocardial infarction. N Engl J Med 1993; 329: 673-682.

24. Brilakis ES, Mavrogiorgos NC, Kopecky SL, et al. Usefulness of QRS duration in the absence of bundle branch block as an early predictor of survival in non-ST elevation acute myocardial infarction. Am J Cardiol 2002; 89: 1013-1018.

25. Tsukahara K, Kimura K, Kosuge M, et al. Clinical implications of intermediate QRS prolongation in the absence of bundle-branch block in patients with STsegment-elevation acute myocardial infarction. Circ J 2005; 69: 29-34.

26. Ilkhanoff L, Liu K, Ning H, et al. Association of QRS duration with left ventricular structure and function and risk of heart failure in middle-aged and older adults: the Multi-Ethnic Study of Atherosclerosis (MESA). Eur J Heart Fail 2012; 14: 1285-1292.

27. Kurisu S, Sumimoto $Y$, Ikenaga $H$, et al. Association of QRS duration with left ventricular volume and ejection fraction after anterior myocardial infarction assessed by gated single photon emission computed tomography. Acta Cardiol 2018; 73: 371-376.

28. Bader H, Garrigue S, Lafitte S, et al. Intra-left ventricular electromechanical asynchrony. A new independent predictor of severe cardiac events in heart failure patients. J Am Coll Cardiol 2004; 43: 248-256.
29. Terho HK, Tikkanen JT, Kentta TV, et al. Electrocardiogram as a predictor of sudden cardiac death in middle-aged subjects without a known cardiac disease. Int J Cardiol Heart Vasc 2018; 20: 50-55.

30. Goldberger JJ, Cain ME, Hohnloser SH, et al.; American Heart A, American College of Cardiology F and Heart Rhythm S. American Heart Association/American College of Cardiology Foundation/Heart Rhythm Society scientific statement on noninvasive risk stratification techniques for identifying patients at risk for sudden cardiac death: a scientific statement from the American Heart Association Council on Clinical Cardiology Committee on Electrocardiography and Arrhythmias and Council on Epidemiology and Prevention. Circulation 2008; 118: 1497-1518.

31. Tang AS, Wells GA, Talajic M, et al.; Resynchronization-Defibrillation for Ambulatory Heart Failure Trial I. Cardiac-resynchronization therapy for mild-tomoderate heart failure. N Engl J Med 2010; 363: 2385-2395.

32. Teodorescu C, Reinier K, Uy-Evanado A, et al. Prolonged QRS duration on the resting ECG is associated with sudden death risk in coronary disease, independent of prolonged ventricular repolarization. Heart Rhythm 2011; 8: 1562-1567.

33. Hummel SL, Skorcz S, Koelling TM. Prolonged electrocardiogram QRS duration independently predicts long-term mortality in patients hospitalized for heart failure with preserved systolic function. J Card Fail 2009; 15: 553-560.

34. Joseph J, Claggett BC, Anand IS, et al. QRS Duration is a predictor of adverse outcomes in heart failure with preserved ejection fraction. JACC Heart Fail 2016; 4: 477-486. 